\title{
EFFECT OF STEEL FIBER ON THE MECHANICAL PROPERTIES OF CEMENT- BASED COMPOSITES CONTAINING SILICA FUME
}

Wei-Ting Lin

Department of Harbor and River Engineering, National Taiwan Ocean University, Keelung, Taiwan, R.O.C.

Ran Huang

Department of Harbor and River Engineering, National Taiwan Ocean University, Keelung, Taiwan, R.O.C., ranhuang@mail.ntou.edu.tw

Chin-Lai Lee

Department of Harbor and River Engineering, National Taiwan Ocean University, Keelung, Taiwan, R.O.C.

Hui-Mi Hsu

Department of Civil Engineering, National Ilan University, Ilan, Taiwan, R.O.C.

Follow this and additional works at: https://jmstt.ntou.edu.tw/journal

Part of the Civil and Environmental Engineering Commons

\section{Recommended Citation}

Lin, Wei-Ting; Huang, Ran; Lee, Chin-Lai; and Hsu, Hui-Mi (2008) "EFFECT OF STEEL FIBER ON THE MECHANICAL PROPERTIES OF CEMENT-BASED COMPOSITES CONTAINING SILICA FUME," Journal of Marine Science and Technology. Vol. 16: Iss. 3, Article 7.

DOI: $10.51400 / 2709-6998.2010$

Available at: https://jmstt.ntou.edu.tw/journal/vol16/iss3/7

This Research Article is brought to you for free and open access by Journal of Marine Science and Technology. It has been accepted for inclusion in Journal of Marine Science and Technology by an authorized editor of Journal of Marine Science and Technology. 


\title{
EFFECT OF STEEL FIBER ON THE MECHANICAL PROPERTIES OF CEMENT-BASED COMPOSITES CONTAINING SILICA FUME
}

\author{
Wei-Ting Lin*, Ran Huang*, Chin-Lai Lee*, and Hui-Mi Hsu**
}

Key words: direct tensile strength, abrasion coefficient, toughness, impact number, multiple regression analysis.

\begin{abstract}
An experimental program was carried out to evaluate the mechanical properties of cement-based composites. Test variables included water to cementitious ratio, dosage of silica fume and volume fraction of steel fiber. Compressive strength test, direct tensile strength test, splitting tensile strength test, abrasion resistance test and drop weight test were performed and the results were analyzed statistically. According to the results of this study, the designed direct tensile testing method was a suitable method to estimate the tensile strength of fiber cement-based composites. Addition of fibers provided better performance for the cement-based composites, while silica fume in the composites would help obtaining uniform fiber dispersion in the matrix and improve strength and the bonding between fiber and matrix resulting from extra dense calcium-silicate-hydrate gel. The combination of steel fibers and silica fume can greatly increase the mechanical properties of cement-based composites. Besides, a multiple regression analysis was conducted to correlate compressive strength, direct tensile strength, abrasion coefficient and impact number with $\mathrm{w} / \mathrm{cm}$ ratio, silica fume content and steel fiber content and a fairly agreement between test data and estimated values was found.
\end{abstract}

\section{INTRODUCTION}

Cement-based composites have long been used for civil structures such as highways, bridges and buildings. However, unexpected deterioration of reinforced or pre-stressed concrete structures has led to the improvement of durability of concrete. Traditionally, the constituents of cement-based composites include cementitious material, water, aggregate and/or admix-

Paper submitted 05/04/07; accepted 09/07/07. Author for correspondence: Ran Huang (e-mail: ranhuang@mail.ntou.edu.tw).

*Department of Harbor and River Engineering, National Taiwan Ocean University, Keelung, Taiwan, R.O.C.

**Department of Civil Engineering, National Ilan University, Ilan, Taiwan, R.O.C. tures. Fiber has been added in cement-based composites since 1960 's to enhance concrete properties, particularly tensile strength, abrasion resistance and energy absorbing capacity $[4,8,11]$. The presence of fiber would refrain the growth or propagation of internal cracks and helps to transfer load $[9,13]$. The specimen with fiber has much higher ductility than the specimen without fiber, for which fiber reinforced composites (FRC) also demonstrates a significant increase in energy absorption or toughness [7]. However, the properties of FRC would be affected by the type, volume fraction and aspect ratio of fiber. Lower fiber volume fraction is usually preferred as far as material cost and workability are concerned [1]. The previous research has suggested that the proper volume fraction of fiber was around $2 \%$ in cement-based composites [10].

It was also reported that the combination of silica fume with steel fiber would effectively enhance the compressive strength, splitting tensile strength, abrasion resistance and impact resistance [5] and be beneficial for fiber dispersion in cement-based composites [2-3]. Silica fume would increase the bonding between fiber and mortar [6] by strengthening the interfacial zone [14]. This study was aimed to evaluate the effect of steel fiber on the mechanical properties of cement-based composites with silica fume. A multiple regression analysis was also performed on the experimental results to quantify the influence of material variables on the mechanical properties.

\section{EXPERIMENTAL PROGRAM}

\section{Materials and Mix Proportions}

Type I Portland cement conforming to ASTM C150-05 was used in all mixes. Silica fume with specific gravity of 2.20 and specific surface area of $22500 \mathrm{~m}^{2} / \mathrm{kg}$ was used. The diameter of silica fume particle was about $0.1-0.2 \mu \mathrm{m}$. The chemical compositions of cement and silica fume are listed in Table 1. Hooked-end steel fiber with an aspect ratio $(l / \mathrm{d})$ of 40 was applied. The average length and tensile strength of steel fiber was $30 \mathrm{~mm}$ and $1100 \mathrm{~N} / \mathrm{mm}^{2}$, respectively.

The water/cementitious ratios were kept at 0.35 and 0.55 , respectively. The maximum size of coarse aggregates was $13 \mathrm{~mm}$ and the fineness modulus of fine aggregates was 2.87 . Mixture slump was controlled around $150 \mathrm{~mm}$ by adjusting 
Table 1. Composition and specific gravity of cement and silica fume. \begin{tabular}{|l|l|l|}
\hline Chemical composition & Portland cement & Silica fume \\
\hline
\end{tabular}

\begin{tabular}{|c|c|c|}
\hline $\mathrm{SiO}_{2}(\%)$ & 21.2 & 91.5 \\
\hline $\mathrm{Al}_{2} \mathrm{O}_{3}(\%)$ & 5.4 & 0.2 \\
\hline $\mathrm{Fe}_{2} \mathrm{O}_{3}(\%)$ & 3.2 & 0.7 \\
\hline $\mathrm{CaO}(\%)$ & 63.8 & 0.4 \\
\hline $\mathrm{MgO}(\%)$ & 2.0 & 1.5 \\
\hline $\mathrm{SO}_{3}(\%)$ & 2.2 & 0.5 \\
\hline L.O.I. ${ }^{*}(\%)$ & 0.7 & 1.4 \\
\hline $\mathrm{K}_{2} \mathrm{O}+\mathrm{Na}_{2} \mathrm{O}(\%)$ & 0.8 & 1.9 \\
\hline Others $(\%)$ & 0.7 & 1.9 \\
\hline Specific gravity & 3.15 & 2.20 \\
\hline
\end{tabular}

Table 2. Mix design $\left(\mathrm{kg} / \mathrm{m}^{3}\right)$.

\begin{tabular}{|c|c|c|c|c|c|c|c|c|}
\hline $\begin{array}{c}\text { Mix } \\
\text { no. }\end{array}$ & w/cm* & Water & Cement & $\begin{array}{c}\text { Silica } \\
\text { fume }\end{array}$ & $\begin{array}{c}\text { Fine } \\
\text { aggre- } \\
\text { gate }\end{array}$ & $\begin{array}{c}\text { Coarse } \\
\text { aggre- } \\
\text { gate }\end{array}$ & Fiber & SP $^{* *}$ \\
\hline A & 0.35 & 189.4 & 558.0 & 0 & 908 & 700 & 0 & 5.6 \\
\hline A1 & 0.35 & 189.4 & 558.0 & 0 & 901 & 694 & 39 & 5.6 \\
\hline A2 & 0.35 & 189.4 & 558.0 & 0 & 894 & 687 & 78 & 5.6 \\
\hline A3 & 0.35 & 189.4 & 558.0 & 0 & 881 & 674 & 156 & 5.6 \\
\hline Aa & 0.35 & 189.4 & 530.1 & 27.9 & 908 & 700 & 0 & 5.6 \\
\hline Aa1 & 0.35 & 189.4 & 530.1 & 27.9 & 901 & 694 & 39 & 5.6 \\
\hline Aa2 & 0.35 & 189.4 & 530.1 & 27.9 & 894 & 687 & 78 & 5.6 \\
\hline Aa3 & 0.35 & 189.4 & 530.1 & 27.9 & 881 & 674 & 156 & 5.6 \\
\hline Ab & 0.35 & 189.4 & 502.2 & 55.8 & 908 & 700 & 0 & 5.6 \\
\hline Ab1 & 0.35 & 189.4 & 502.2 & 55.8 & 901 & 694 & 39 & 5.6 \\
\hline Ab2 & 0.35 & 189.4 & 502.2 & 55.8 & 894 & 687 & 78 & 5.6 \\
\hline Ab3 & 0.35 & 189.4 & 502.2 & 55.8 & 881 & 674 & 156 & 5.6 \\
\hline B & 0.55 & 217.0 & 395.0 & 0 & 908 & 780 & 0 & 0 \\
\hline B1 & 0.55 & 217.0 & 395.0 & 0 & 901 & 773 & 39 & 0 \\
\hline B2 & 0.55 & 217.0 & 395.0 & 0 & 894 & 767 & 78 & 0 \\
\hline B3 & 0.55 & 217.0 & 395.0 & 0 & 881 & 753 & 156 & 0 \\
\hline Ba & 0.55 & 217.0 & 375.2 & 19.8 & 908 & 780 & 0 & 0 \\
\hline Ba1 & 0.55 & 217.0 & 375.2 & 19.8 & 901 & 773 & 39 & 0 \\
\hline Ba2 & 0.55 & 217.0 & 375.2 & 19.8 & 894 & 767 & 78 & 0 \\
\hline Ba3 & 0.55 & 217.0 & 375.2 & 19.8 & 881 & 753 & 156 & 0 \\
\hline Bb & 0.55 & 217.0 & 355.5 & 39.5 & 908 & 780 & 0 & 0 \\
\hline Bb1 & 0.55 & 217.0 & 355.5 & 39.5 & 901 & 773 & 39 & 0 \\
\hline Bb2 & 0.55 & 217.0 & 355.5 & 39.5 & 894 & 767 & 78 & 0 \\
\hline Bb3 & 0.55 & 217.0 & 355.5 & 39.5 & 881 & 753 & 156 & 0 \\
\hline$*$ water/cementitious ratio & & & & & \\
$* * *$ superplasticizer & & & & & & \\
\hline
\end{tabular}

proper amount of high-range water-reducing admixture in the mixes. The details of mix proportions of FRC are shown in Table 2. Portland cement was partially replaced by silica fume with dosages of 5 wt. $\%$ and 10 wt. $\%$, respectively. Steel fibers with volume fractions of $0.5 \%, 1.0 \%$ and $2.0 \%$ were used in the mixes.

Specimens with a total of 24 different mixes were cast. For each mix, twenty-one $\phi 100 \times 200 \mathrm{~mm}$ cylindrical specimens for compressive strength test, six $\phi 150 \times 300 \mathrm{~mm}$ cylindrical specimens for direct and splitting tensile strength tests and six $\phi 150 \times 64 \mathrm{~mm}$ circular discs for abrasion resistance test and drop weight test were prepared and cured in saturated lime

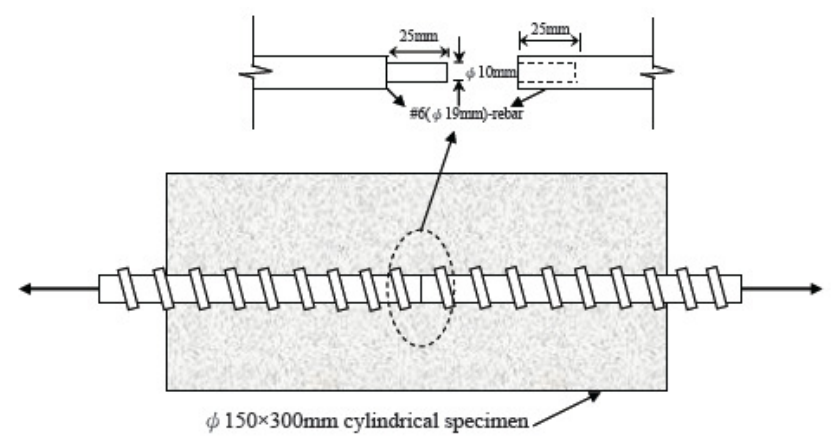

(a) specimen

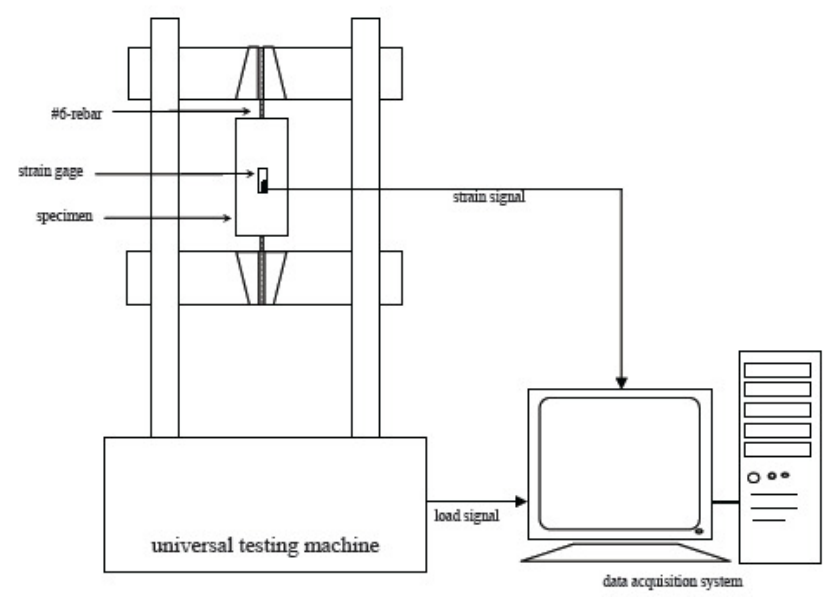

(b) direct tensile test set-up

Fig. 1. The frame structure of the transmitted bit stream.

water until testing.

\section{Testing Methods}

Compressive strength tests at ages of 7, 14, 28, 56, 91 and 120 days were performed in accordance with ASTM C39-03. Splitting tensile strength test was conducted in accordance with ASTM C496-04. The designed direct tensile test method is a relatively new test method which is modified from previous study [12]. Direct tensile strength test was designed and set up as illustrated in Fig. 1. Two rebars (\#6) were placed along with the longitudinal axis of $\phi 150 \times 300 \mathrm{~mm}$ cylindrical specimen and a hole with a diameter of $10 \mathrm{~mm}$ with a length of $25 \mathrm{~mm}$ in the central part was drilled in one rebar, and the other rebar was machined into a $\phi 10 \mathrm{~mm}$ cylindrical plug at one end. After the outside rebars of the tensile specimen were gripped by the jaws, tensile loading was applied at $50 \mathrm{kgf} / \mathrm{min}$ until failure.

Abrasion resistance test was conducted following the specifications of ASTM C418-05. The method covers the determination of abrasion resistance characteristics of FRC by subjecting the specimen to the impingement of air-driven silica sand, and abrasion coefficient was determined accordingly. The abrasion coefficient, an index of abrasion resistance, is computed as $A_{c}=V / A$, in which $A$ is the abraded surface area and $V$ is the volume loss by abrasion. 
Table 3. Mechanical properties of FRC specimens.

\begin{tabular}{|c|c|c|c|c|c|}
\hline Mix no. & $\begin{array}{c}f_{c}^{\prime} \\
(\mathrm{MPa})\end{array}$ & $\begin{array}{c}f_{s p} \\
(\mathrm{MPa})\end{array}$ & $\begin{array}{c}f_{\text {dir }} \\
(\mathrm{MPa})\end{array}$ & $\begin{array}{c}A_{c} \\
\left(\mathrm{x} 10^{-3}, \mathrm{~cm}^{3} / \mathrm{cm}^{2}\right)\end{array}$ & $\begin{array}{c}\text { Toughness } \\
\text { index }\end{array}$ \\
\hline $\mathrm{A}$ & 56.85 & 3.86 & 3.51 & 4.14 & 1.00 \\
\hline $\mathrm{A} 1$ & 57.66 & 4.20 & 3.73 & 3.62 & 1.22 \\
\hline $\mathrm{A} 2$ & 60.18 & 5.44 & 4.10 & 3.41 & 1.38 \\
\hline $\mathrm{A} 3$ & 59.43 & 5.51 & 4.12 & 3.22 & 1.43 \\
\hline $\mathrm{Aa}$ & 61.99 & 3.94 & 3.60 & 3.45 & 1.23 \\
\hline $\mathrm{Aa} 1$ & 62.71 & 4.23 & 3.92 & 3.23 & 1.39 \\
\hline $\mathrm{Aa} 2$ & 63.03 & 5.58 & 4.52 & 3.07 & 1.45 \\
\hline $\mathrm{Aa} 3$ & 63.62 & 6.29 & 4.61 & 2.85 & 1.60 \\
\hline $\mathrm{Ab}$ & 67.24 & 3.95 & 3.62 & 2.80 & 1.40 \\
\hline $\mathrm{Ab} 1$ & 68.21 & 4.44 & 4.04 & 2.54 & 1.50 \\
\hline $\mathrm{Ab} 2$ & 72.32 & 5.82 & 4.66 & 2.37 & 1.59 \\
\hline $\mathrm{Ab} 3$ & 72.77 & 6.55 & 4.71 & 2.21 & 1.63 \\
\hline $\mathrm{B}$ & 36.90 & 3.11 & 3.26 & 6.47 & 1.00 \\
\hline $\mathrm{B} 1$ & 38.37 & 3.35 & 3.60 & 5.28 & 1.22 \\
\hline $\mathrm{B} 2$ & 38.96 & 3.58 & 3.69 & 5.25 & 1.33 \\
\hline $\mathrm{B} 3$ & 38.55 & 3.94 & 3.77 & 5.14 & 1.35 \\
\hline $\mathrm{Ba}$ & 39.83 & 3.38 & 3.49 & 4.34 & 1.19 \\
\hline $\mathrm{Ba} 1$ & 41.09 & 4.02 & 3.63 & 3.69 & 1.27 \\
\hline $\mathrm{Ba} 2$ & 41.97 & 4.57 & 3.78 & 3.52 & 1.35 \\
\hline $\mathrm{Ba} 3$ & 42.13 & 5.23 & 3.91 & 3.49 & 1.40 \\
\hline $\mathrm{Bb}$ & 42.48 & 3.65 & 3.51 & 3.76 & 1.38 \\
\hline $\mathrm{Bb} 1$ & 44.89 & 4.11 & 3.66 & 3.50 & 1.47 \\
\hline $\mathrm{Bb} 2$ & 45.32 & 4.77 & 3.83 & 3.25 & 1.57 \\
\hline $\mathrm{Bb3}$ & 45.76 & 5.46 & 4.00 & 3.21 & 1.66 \\
\hline
\end{tabular}

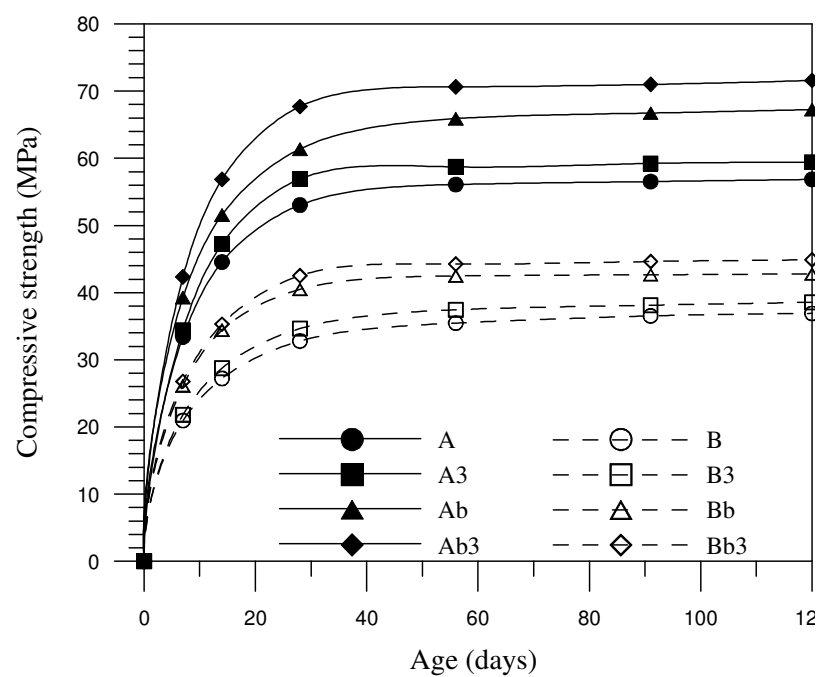

Fig. 2. Compressive strength development curves.

Impact resistance was performed following the recommendation of ACI committee 544. It is suggested to repeat to drop a $63.5 \mathrm{~mm}$-diameter and $4.54 \mathrm{~kg}$ steel ball from a height of 914 $\mathrm{mm}$ on the specimen until the first visible crack is found and then to record the drop number. Failure is defined as the crack opening to let specimen touch at least three of the four positioning lugs on the base plate.

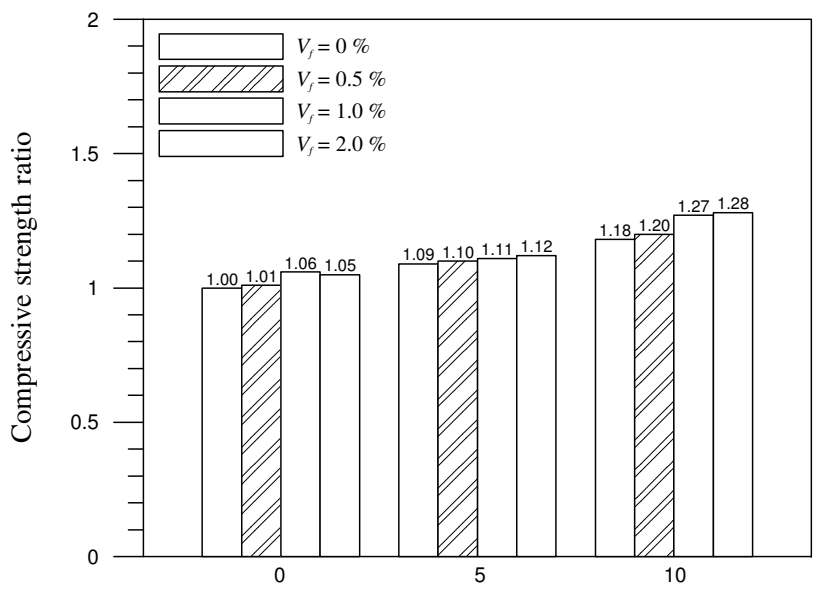

Silica fume content (wt. \%)

Fig. 3. Compressive strength ratio vs. Silica fume content $(w / c m=0.35)$.

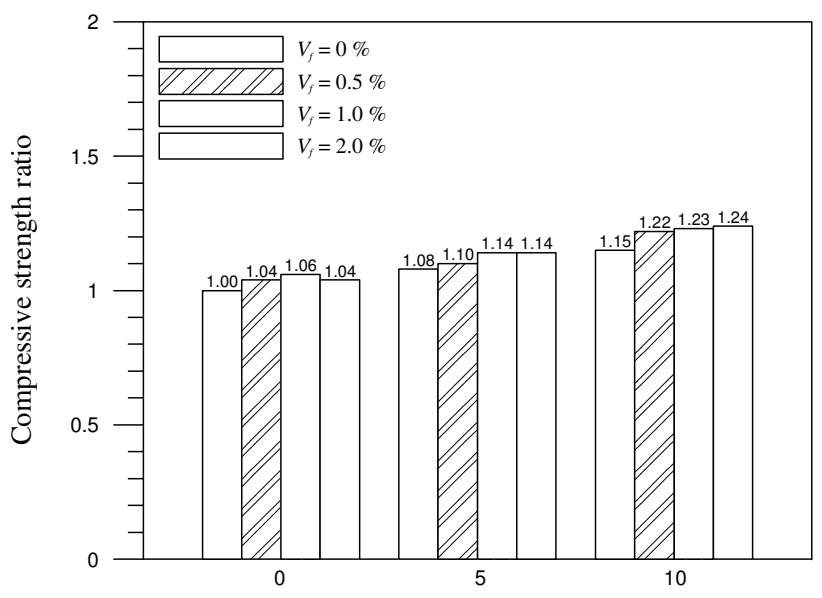

Silica fume content (wt. \%)

Fig. 4. Compressive strength ratio vs. Silica fume content $(w / \mathbf{c m}=0.55)$.

\section{RESULTS AND DISCUSSION}

\section{Compressive Strength}

Compressive strengths, splitting tensile strengths, direct tensile strengths and abrasion coefficient of FRC specimens are represented by $f_{c}^{\prime}, f_{s p}, f_{d i r}$ and $A_{c}$ as given in Table 3 . The compressive strength development curves are plotted in Fig. 2. For all the mixes, the compressive strength increases with age and 120-day strength is about the same as 56-day strength. Silica fume as fineness substitute in composites appears to improve the compressive strength significantly, which is consistent to the previous findings [3]. FRC specimens with silica fume have higher (up to 5\%) compressive strengths than the specimens without silica fume. The presence of silica fume would help dispersing fibers in the mix and strengthen the bond between the fiber and the matrix.

The120-day compressive strength ratios of tested specimens over control specimens as were computed and listed in Figs. 3 


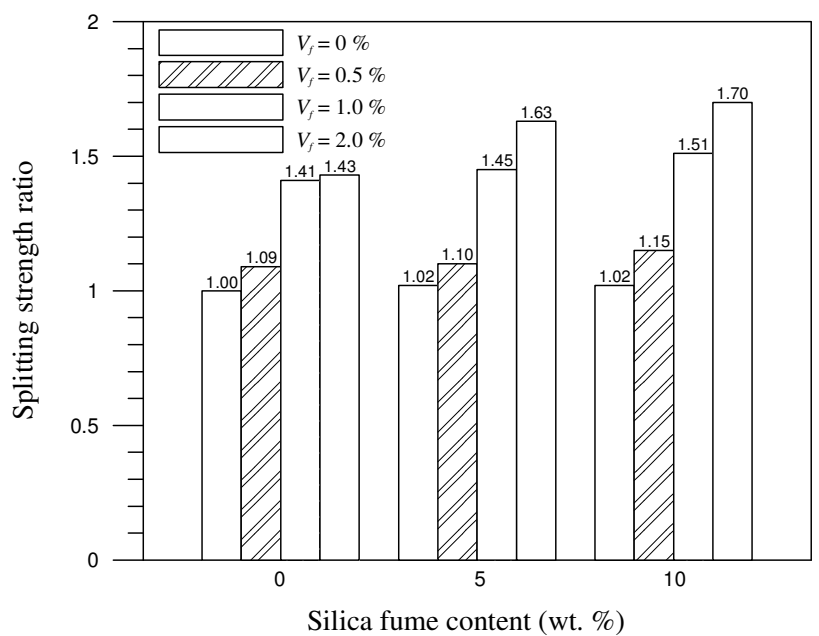

Fig. 5. Splitting strength ratio vs. Silica fume content $(w / \mathrm{cm}=0.35)$.

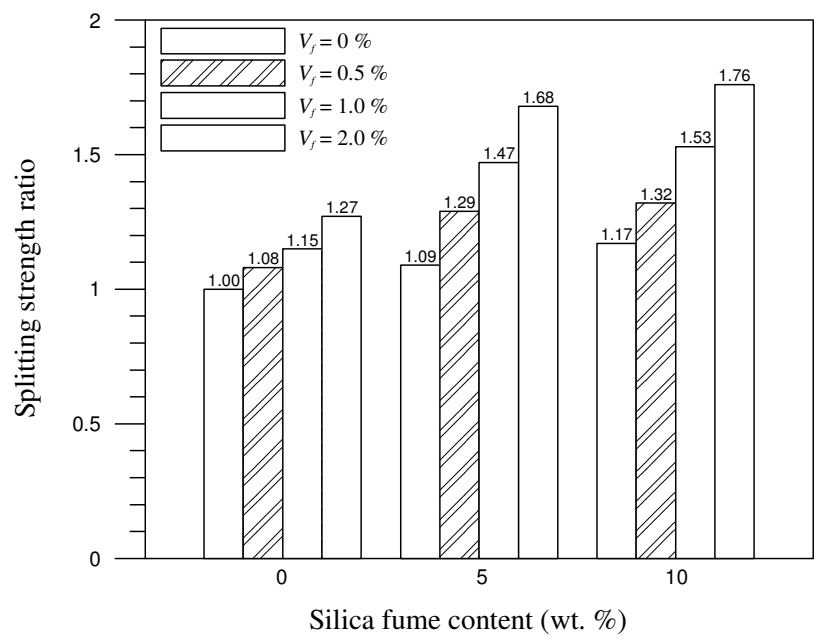

Fig. 6. Splitting strength ratio vs. Silica fume content $(w / c m=0.55)$.

and 4. The addition of silica fume evidently increases the compressive strength of cement-based composite. The specimens with $5 \%$ and $10 \%$ silica fume have $8 \%, 9 \%, 15 \%$ and $18 \%$ higher compressive strength than the specimens with $\mathrm{w} / \mathrm{cm}$ ratios of 0.55 and 0.35 , respectively. The strengthening is due to the pozzolanic activity of silica fume causing improved strength of the composites.

Steel fiber has less effect on the compressive strength by comparing with silica fume. FRC specimens with various volume fractions have a little improvement in compressive strength (about $1 \%$ to $6 \%$ ). The specimen with $2 \%$ fibers has less compressive strength than the specimen with $1 \%$ fibers, which would result from the difficulty of dispersion of $2 \%$ fibers. However, silica fume having a particle size of around $0.1 \mu \mathrm{m}$ appears to help dispersing the fibers in the mix. By combining with the filling effect, silica fume would significantly improve the compressive strength and higher silica fume replacement (up to $10 \%$ ) would have higher strength efficiency as indicated in Figs. 3 and 4. For a given w/cm ratio, specimen with $10 \%$ silica fume and $2 \%$ fiber has highest compressive strength.

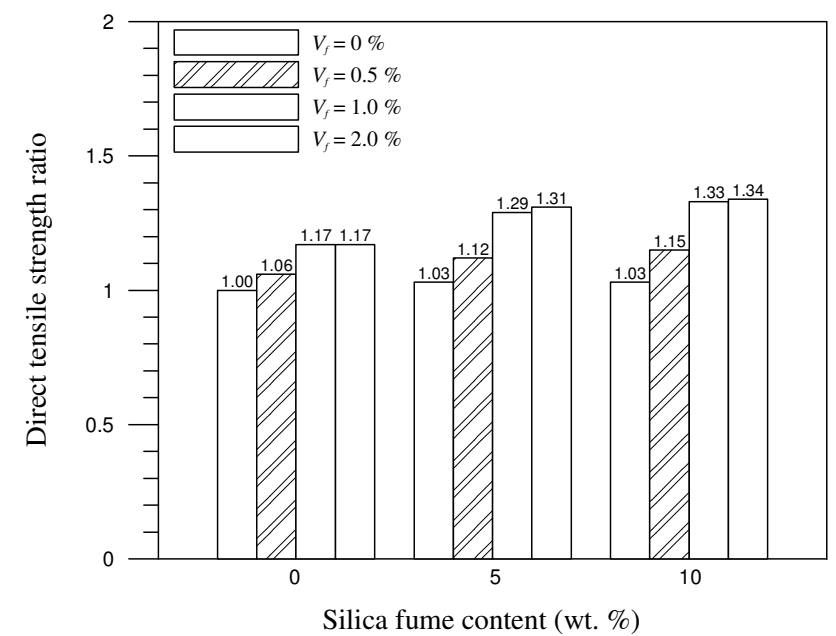

Fig. 7. Direct tensile strength ratio vs. Silica fume content $(\mathrm{w} / \mathrm{cm}=\mathbf{0 . 3 5})$.

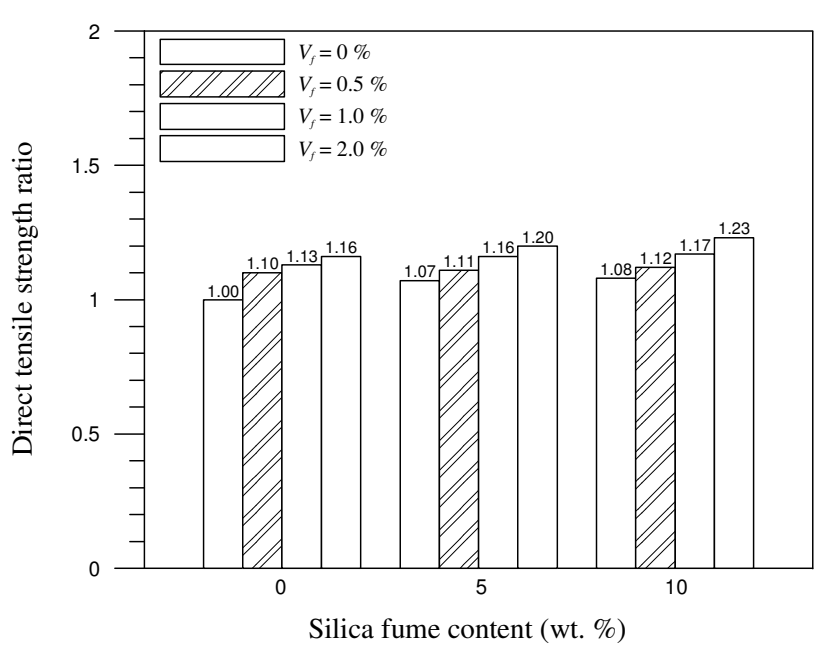

Fig. 8. Direct tensile strength ratio vs. Silica fume content $(\mathrm{w} / \mathrm{cm}=\mathbf{0 . 5 5})$.

\section{Tensile Strength}

Splitting strength ratio is plotted in Figs. 5 and 6. Silica fume has little influence on the splitting tensile strength for specimens with a w/cm ratio of 0.35 . But for the specimens with a w/cm ratio of 0.55 , the splitting tensile strength increases up to $9 \%$ as the silica fume content increases to $5 \%$, which may result from refined pore system achieved by increasing dense hydrated calcium silicate in the mixes.

The splitting tensile strength evidently becomes higher with the fiber inclusion as illustrated in Figs. 5 and 6. The inclusion of steel fiber in the composites plays an important role on splitting tensile strength, about $27 \%$ and $43 \%$ increase with steel fiber addition up to $2 \%$ with a w/cm ratio of 0.55 and 0.35 , respectively. The maximum increasing percentage of the splitting tensile strength is about $70 \%$ and $76 \%$ by incorporating $10 \%$ silica fume and $2 \%$ fiber. The beneficial effect is also achieved by reducing the interfacial porosity and improving the bond between fiber and matrix with extra dense calcium-silicate-hydrate gel obtained from silica fume addition.

The direct tensile strength increases up to $23 \%$ and $34 \%$ with 


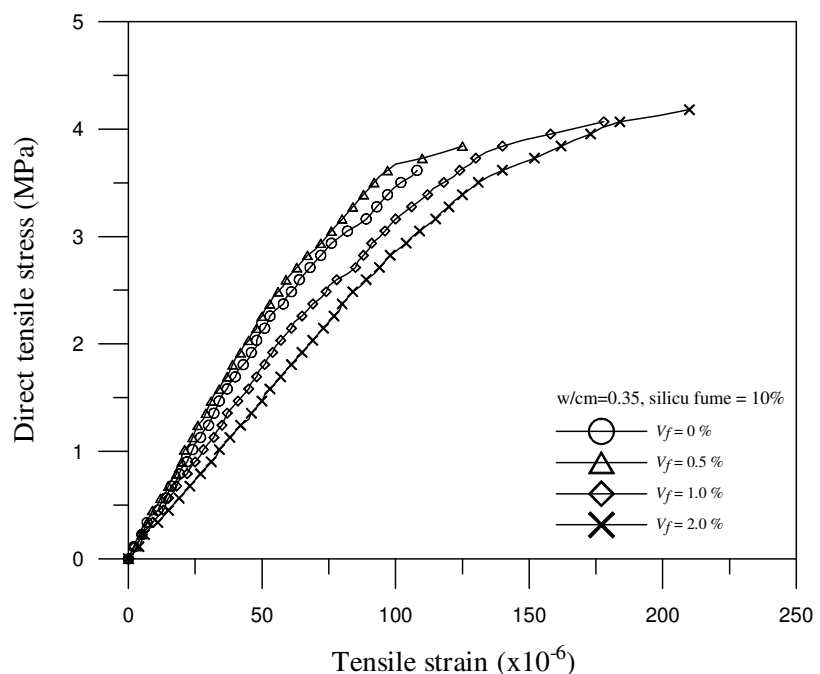

Fig. 9. Stress-strain curves of $\mathrm{FRC}$ with $10 \%$ silica fume $(\mathrm{w} / \mathrm{cm}=\mathbf{0 . 3 5})$.

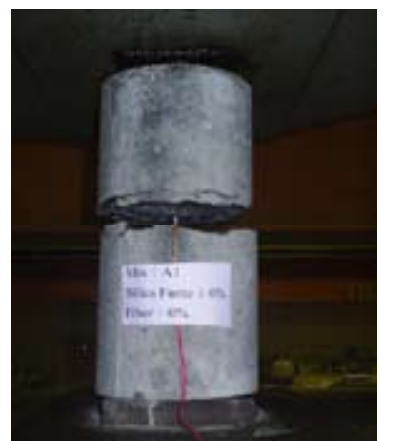

(a) specimen A

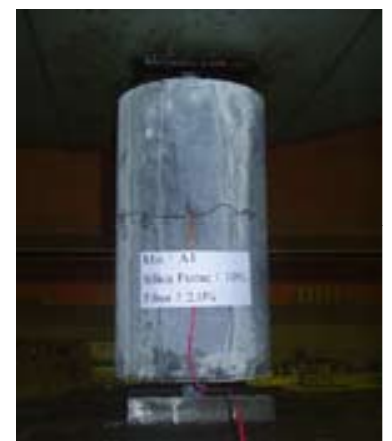

(b) specimen Ab3
Fig. 10. Failure mode of specimens.

the increasing of fiber and silica fume content as illustrated in Figs. 7 and 8. The splitting tensile strengths are higher than the direct tensile strengths for all the specimens. The tension-resisting capacity of FRC specimen depends mainly on the interfacial bond between fiber and matrix. Proper amount of fibers would be beneficial to transfer energy and restrain cracks initiation and propagation. Combination of silica fume and steel fiber in the mixes can increase the capability of crack arresting and pullout force of fibers. The splitting tensile strength is about $8 \%$ higher than the direct tensile strength for ordinary concrete and about $30 \%$ higher than the direct tensile strength for concretes with silica fume and steel fiber. The confining effect is enhanced by lowering w/c ratio and adding silica fume in the mixes.

The tensile stress-strain curves of FRC specimens with 10\% silica fume are presented in Fig. 9 and the toughness index is listed in Table 3. It is evident the stress-strain curve represents the strain capacity and the toughness. Addition of 0.5 vol. $\%, 1.0$ vol. $\%$ and 2.0 vol. $\%$ fibers increases strain capacity by $10 \%$, $19 \%$ and $23 \%$, respectively. The composites with high strain capacity and toughness reflect higher ability to arrest cracks. In summary, fiber content affects the ability of crack arresting and silica fume affect the interfacial bonding. Combination silica

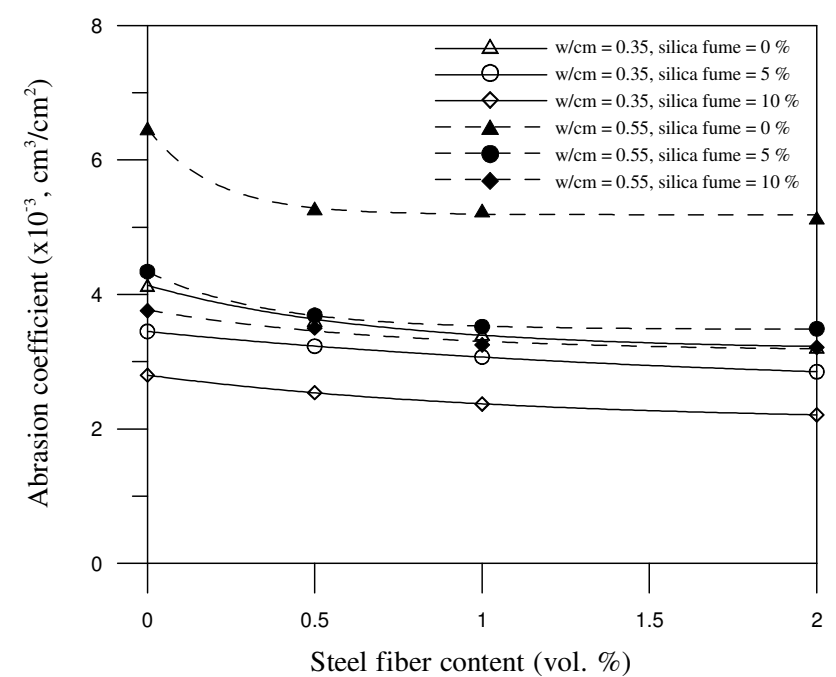

Fig. 11. Abrasion coefficient vs. Fiber content.

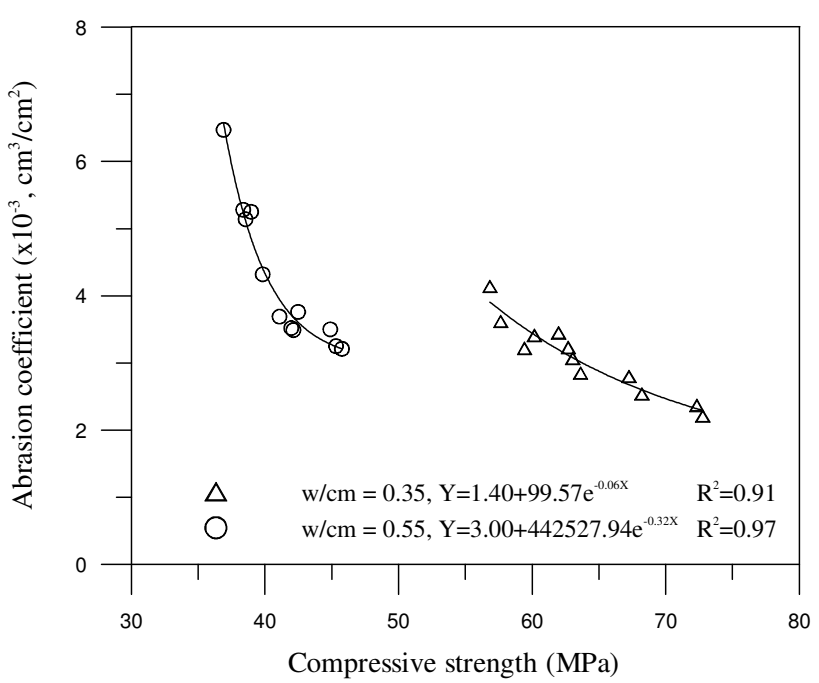

Fig. 12. Abrasion coefficient vs. Compressive strength.

fume with steel fiber, the interfacial structure is improved effectively and the advantage of FRC would be expanded. Two aligned rebars are embedded in the cylindrical specimen to transmit the uniaxial force to concrete. The fracture is located in the middle portion as illustrated in Fig. 10.

\section{Abrasion Resistance Test}

The abrasion coefficient of specimen decreases as the fiber and silica fume content increases as indicated in Fig. 11. Inclusion of 0.5 vol. \% steel fibers in the composites remarkably decreases the abrasion coefficient. However, the abrasion coefficient did not significantly change when the steel fiber content exceeded 1 vol. \%. The abrasion coefficient also decreases with the increase of silica fume content for the specimens with both w/cm ratios. The addition of steel fiber in the composites produces a denser and stronger surface, which resulting in higher resistance to wear. The abrasion coefficient of specimen A2f3 and B2f3 is $2.21 \times 10^{-3}$ and $3.21 \times 10^{-3}\left(\mathrm{~cm}^{3} / \mathrm{cm}^{2}\right)$, respectively, which is about $50 \%$ lower than that of control specimen. 
Table 4. Drop weight test results.

\begin{tabular}{|c|c|c|c|c|}
\hline Mix no. & $\begin{array}{l}\text { Impact number } \\
\text { of initial crack, } \\
\mathrm{N}_{1}\end{array}$ & $\begin{array}{c}\text { Impact number } \\
\text { of ultimate } \\
\text { failure, } \mathrm{N}_{2}\end{array}$ & $\begin{array}{c}\text { Difference } \\
\text { between } \mathrm{N}_{1} \\
\text { and } \mathrm{N}_{2}, \triangle \mathrm{N}\end{array}$ & $\begin{array}{c}\text { Impact } \\
\text { toughness } \\
(\mathrm{KN}-\mathrm{m})\end{array}$ \\
\hline $\mathrm{A}$ & 59 & 63 & 4 & 2.54 \\
\hline A1 & 54 & 70 & 16 & 2.82 \\
\hline $\mathrm{A} 2$ & 86 & 113 & 27 & 4.56 \\
\hline A3 & 88 & 133 & 45 & 5.37 \\
\hline $\mathrm{Aa}$ & 4 & 19 & 15 & 0.77 \\
\hline Aal & 20 & 43 & 23 & 1.73 \\
\hline $\mathrm{Aa} 2$ & 70 & 116 & 46 & 4.68 \\
\hline Aa3 & 115 & 175 & 60 & 7.06 \\
\hline $\mathrm{Ab}$ & 7 & 11 & 4 & 0.44 \\
\hline $\mathrm{Ab} 1$ & 19 & 32 & 13 & 1.29 \\
\hline $\mathrm{Ab} 2$ & 70 & 128 & 58 & 5.16 \\
\hline Ab3 & 350 & 460 & 110 & 18.56 \\
\hline $\mathrm{B}$ & 98 & 103 & 5 & 4.16 \\
\hline $\mathrm{B} 1$ & 110 & 129 & 19 & 5.20 \\
\hline $\mathrm{B} 2$ & 130 & 171 & 41 & 6.90 \\
\hline B3 & 222 & 252 & 30 & 10.17 \\
\hline $\mathrm{Ba}$ & 30 & 33 & 3 & 1.33 \\
\hline Bal & 27 & 47 & 20 & 1.90 \\
\hline $\mathrm{Ba} 2$ & 40 & 92 & 52 & 3.71 \\
\hline $\mathrm{Ba} 3$ & 71 & 135 & 64 & 5.45 \\
\hline $\mathrm{Bb}$ & 35 & 39 & 4 & 1.57 \\
\hline Bb1 & 33 & 46 & 13 & 1.86 \\
\hline $\mathrm{Bb} 2$ & 35 & 53 & 18 & 2.14 \\
\hline Bb3 & 94 & 154 & 60 & 6.21 \\
\hline
\end{tabular}

The cement-based composites with $10 \%$ silica fume and $2 \%$ fiber also exhibit excellent abrasion resistance. The abrasion coefficient appears to decrease exponentially with compressive strength as illustrated in Fig. 12. Clearly, the compressive strength affects the abrasion coefficient more prominent for the specimens with higher $w / \mathrm{cm}$ ratio than for the specimens with lower $\mathrm{w} / \mathrm{cm}$ ratio. It is suggested that $\mathrm{w} / \mathrm{cm}$ ratio may play a role on abrasion coefficient besides silica fume and steel fiber contents.

\section{Drop Weight Test}

The impact number is a qualitative estimate of the energy absorption capacity of the specimens and the impact performance is a quantitative index, which is obtained from impact number of initial crack $\left(\mathrm{N}_{1}\right)$, impact number of failure $\left(\mathrm{N}_{2}\right)$, the difference between $\mathrm{N}_{1}$ and $\mathrm{N}_{2}(\triangle \mathrm{N})$ and impact toughness (T). Impact toughness is calculated by $\mathrm{T}=\mathrm{N}_{2} \mathrm{mgh}$, where $\mathrm{m}, \mathrm{g}$ and $\mathrm{h}$ is mass of the ball, acceleration of gravity and height, respectively. The results of drop weight test are summarized in Table 4, which indicates the specimen with higher $w / \mathrm{cm}$ ratio has greater increase in energy absorbed capacity than the specimen with lower $\mathrm{w} / \mathrm{cm}$ ratio. The impact numbers of specimens with silica fume are not much different from the impact number of specimens without silica fume. But as the incorporation of silica fume increases the strength increases, and thus reduce the impact number. However, FRC specimens with proper fiber contents could exhibit less brittle property and usually have higher energy absorbed capacity. The key to improve the performance of cement-based composite under impact loading is to increase its cracking resistance. Steel fibers in the composites can restrain the extension of the crack, change the direction of crack growth and delay the growth rate of the crack, and silica fume can improve the interfacial characteristics. Thus, specimen with $10 \%$ silica fume and 2 vol. \% fibers has 7.3 times energy absorbed capacity than the control specimen.

\section{Multiple Regression Analysis}

The mechanical properties of FRC with silica fume are affected by many factors. For evaluating the influence and the interaction of the considered material variables, multiple regression analysis was conducted by selecting the following independent variables: water/cementitious ratio $(w / \mathrm{cm})$, silica fume content $\left(W_{s}\right)$ and steel fiber content $\left(V_{f}\right)$ and the dependent variables: compressive strength $\left(f_{c}^{\prime}\right)$, splitting tensile strength $\left(f_{s p}\right)$, direct tensile strength $\left(f_{\text {dir }}\right)$, abrasion coefficient $\left(A_{c}\right)$ and impact number $(\triangle N)$. In order to realize the influences of interactions of effects among all the material factors, the regression model is assumed as follows:

$$
\begin{aligned}
& Y=a 1+a 2(w / c m)+a 3\left(W_{s}\right)+a 4\left(V_{f}\right)+a 5(w / c m)\left(W_{s}\right)+ \\
& a 6(w / c m)\left(V_{f}\right)+a 7\left(W_{s}\right)\left(V_{f}\right)+a 8(w / c m)\left(W_{s}\right)\left(V_{f}\right)
\end{aligned}
$$

where $\mathrm{Y}$ is the predicted value and w/cm, $W_{s}, V_{f}$ are the independent variables, a1 is the intercept and a2, a3, a4, a5, a6, a7, and $\mathrm{a} 8$ are the regression coefficients. The results of multiple regression analysis are obtained as below.

$$
\begin{aligned}
& f_{c}^{\prime}=91.74-98.59(w / c m)+1.80\left(W_{s}\right)+1.25\left(V_{f}\right) \\
& -2.21(w / c m)\left(W_{s}\right)-0.97(w / c m)\left(V_{f}\right)+0.31\left(W_{s}\right)\left(V_{f}\right) \\
& -0.43(w / c m)\left(W_{s}\right)\left(V_{f}\right) \\
& f_{s p}=5.43-3.96(w / c m)+0.09\left(W_{s}\right)+1.68\left(V_{f}\right) \\
& +0.27(w / c m)\left(W_{s}\right)-2.15(w / c m)\left(V_{f}\right)+0.04\left(W_{s}\right)\left(V_{f}\right) \\
& +0.01(w / c m)\left(W_{s}\right)\left(V_{f}\right) \\
& f_{\text {dir }}=3.95-1.01(w / c m)+0.02\left(W_{s}\right)+0.55\left(V_{f}\right) \\
& -0.01(w / c m)\left(W_{s}\right)-0.60(w / c m)\left(V_{f}\right)+0.06\left(W_{s}\right)\left(V_{f}\right) \\
& -0.11(w / c m)\left(W_{s}\right)\left(V_{f}\right) \\
& A_{c}=0.88+8.88(w / c m)-0.07\left(W_{s}\right)-0.17\left(V_{f}\right) \\
& -0.56(w / c m)\left(W_{s}\right)-0.66(w / c m)\left(V_{f}\right)-0.10\left(W_{s}\right)\left(V_{f}\right) \\
& +0.70(w / c m)\left(W_{s}\right)\left(V_{f}\right) \\
& \Delta N=4.10+16.67(w / c m)+0.18\left(W_{s}\right)+14.21\left(V_{f}\right) \\
& -2.80(w / c m)\left(W_{s}\right)+3.57(w / c m)\left(V_{f}\right)+7.10\left(W_{s}\right)\left(V_{f}\right) \\
& -10.09(w / c m)\left(W_{s}\right)\left(V_{f}\right)
\end{aligned}
$$

The compressive strength, splitting tensile strength, direct tensile strength, abrasion resistance and impact number are found to exhibit good correlation with experimental values with 


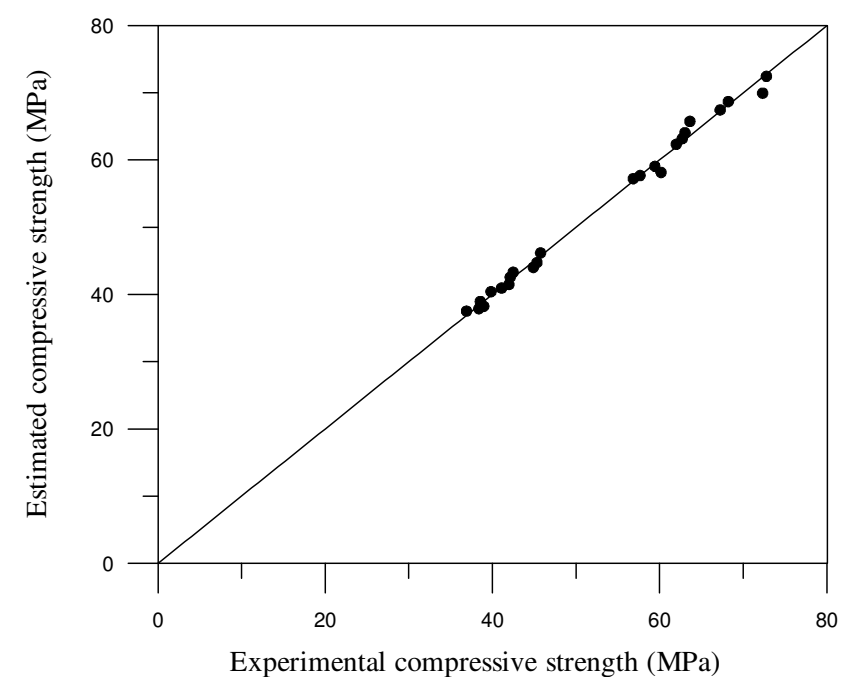

Fig. 13. Estimated values vs. experimental values for compressive strength.

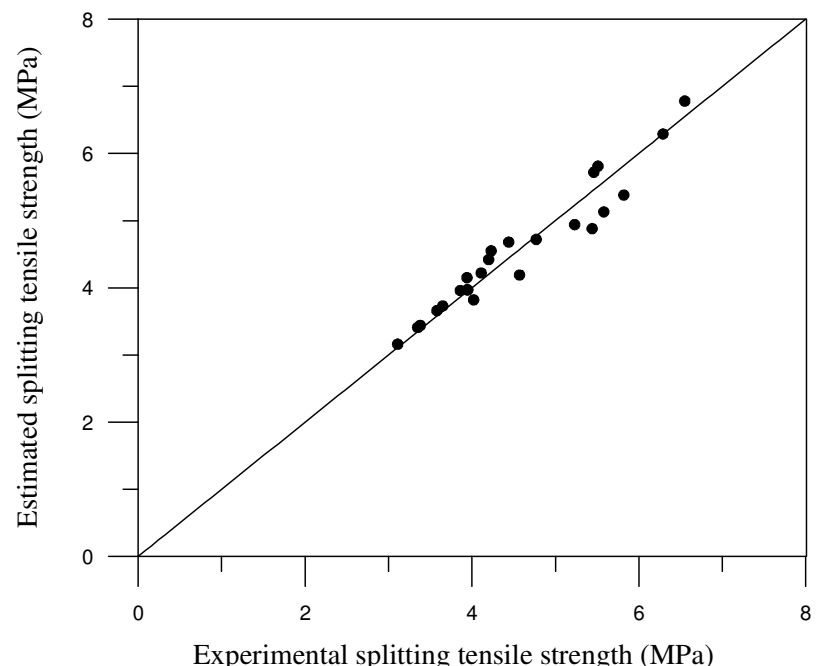

Fig. 14. Estimated values vs. experimental values for splitting tensile strength.

a correlation coefficient of $0.99,0.93,0.88,0.91$ and 0.88 , respectively. The estimated values are plotted versus the experimental values as illustrated in Figs. 13 to 17. The deviation is represented by the distance from each point plots from the diagonal line. In general, the points are uniformly scattered around the diagonal line for all the assumed models. The above analyses indicate that the model parameters strongly depended on the mechanical property tested and that can provide valuable information to predict the mechanical properties of fiber reinforced composites.

\section{CONCLUSION}

Cement-based composites containing 10\% silica fume demonstrates better compressive strength, splitting tensile strength, direct tensile strength and abrasion resistance, and worse impact resistance than composites containing 5\% silica fume. The $10 \%$ silica fume specimens with $w / \mathrm{cm}$ ratios of 0.35 and 0.65 have

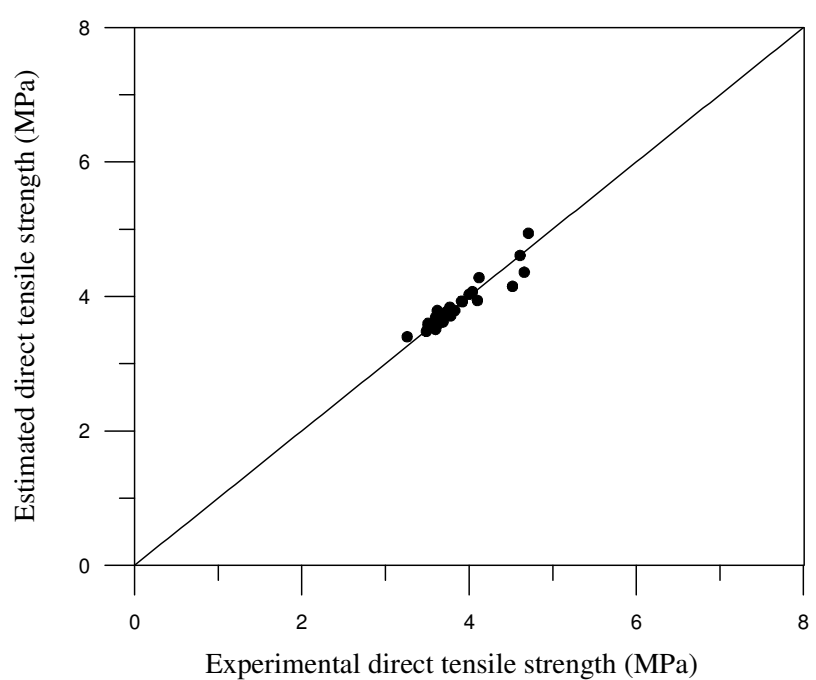

Fig. 15. Estimated values vs. experimental values for direct tensile strength.

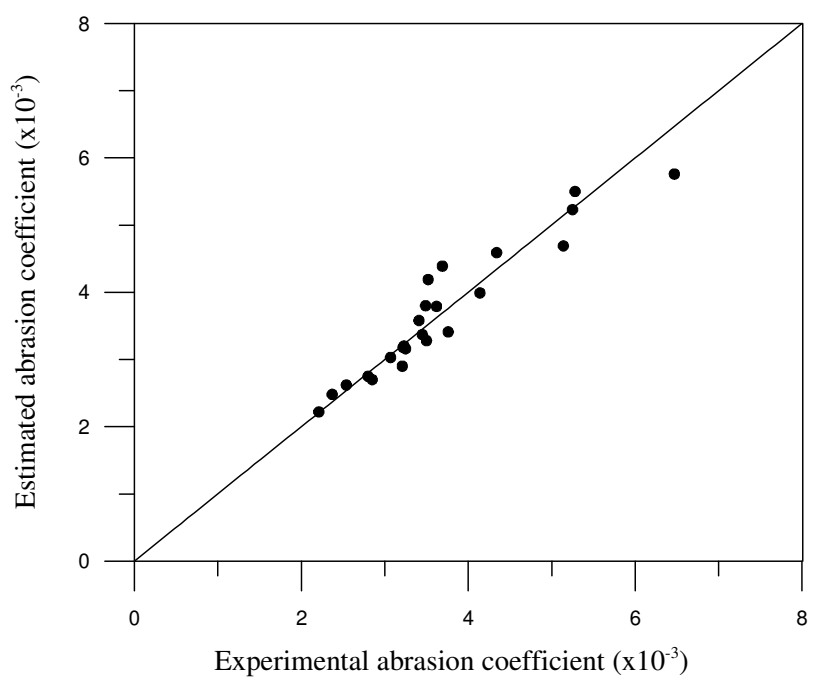

Fig. 16. Estimated values vs. experimental values for abrasion coefficient.

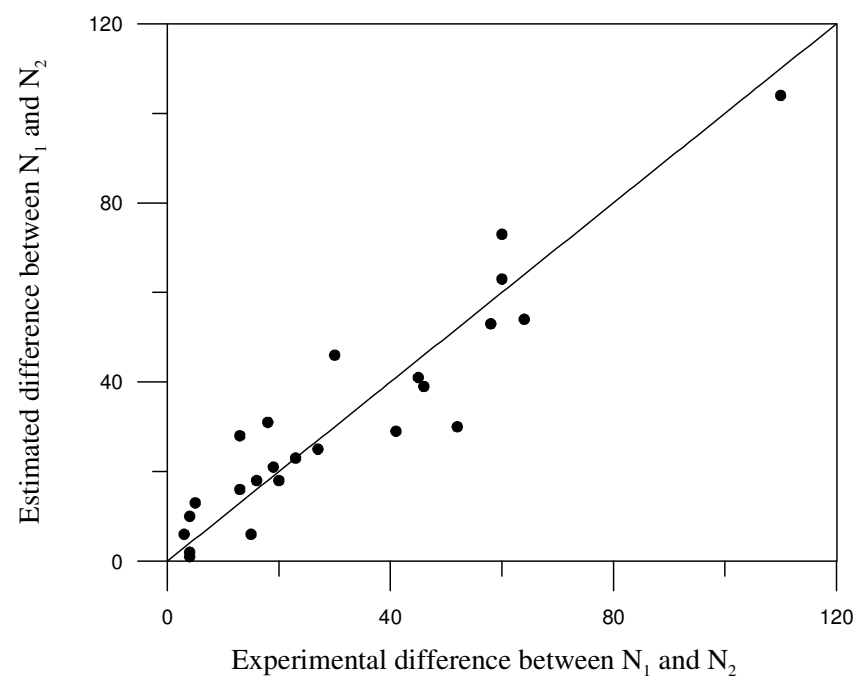

Fig. 17. Estimated values vs. experimental values for drop weight test. 
$18 \%$ and $15 \%$ higher compressive strength, $3 \%$ and $8 \%$ higher direct tensile strength, $40 \%$ and $38 \%$ higher toughness, $32 \%$ and $42 \%$ lower abrasion coefficient and $83 \%$ and $62 \%$ lower impact toughness than the control specimen. The addition of steel fiber to silica fume composites achieves a significant increase in tensile strength, toughness and impact resistance and slight improvements in compressive strength and abrasion resistance. Silica fume composites with steel fiber for mixes A and B obtain an extra average $10 \%$ and $9 \%$ increase in compressive strength, $68 \%$ and $59 \%$ increase in splitting tensile strength, $31 \%$ and $15 \%$ increase in direct tensile strength, $23 \%$ and $28 \%$ increase in toughness, $18 \%$ and $8 \%$ reduction in abrasion coefficient, and $4118 \%$ and $296 \%$ increase in impact toughness. In addition, the designed direct tensile testing method is suitable for determining the tensile strength of FRC specimens. Based on the test data and the results of multiple regression analysis, the mechanical properties of FRC and silica fume composites can be reasonably correlated with $w / \mathrm{cm}$ ratio, silica fume content and steel fiber content.

\section{REFERENCES}

1. Chen, P. W. and Chung, D. D. L., "Low-drying-shrinkage concrete containing carbon fibers," Composites Part B: Engineering, Vol. 27, pp. 269-274 (1996)

2. Chen, P. W., Fu, X., and Chung, D. D. L., "Microstructural and mechanical effects of latex, methyleellulose and silica fume on carbon fiber reinforced cement," ACI Materials Journal, Vol. 94, pp. 147-155 (1997).

3. Chung, D. D. L., "Review-Improving cement-based materials by using Silica Fume," Journal of Materials Science, Vol. 37, pp. 673-682 (2002).

4. de Gutierrez, R. M., Diaz, L. N., and Delvasto, S., "Effect of pozzolans on the performance of fiber-reinforced mortars," Cement and Concrete Composites, Vol. 27, pp. 593-598 (2005).

5. Eren, O., Marar, K., and Celik, T., "Effects of silica fume and steel fibers on some mechanical properties of high-strength fiber-reinforced concrete," Journal of Testing and Evaluation, Vol. 27, pp. 380-387 (1999).

6. Fu, X. and Chung, D. D. L., "Effects of water-cement ratio, curing age, silica fume, polymer admixtures, steel surface treatments, and corrosion on bond between concrete and steel reinforcing bars," ACI Materials Journal, Vol. 95, pp. 725-734 (1998).

7. Kesner, K. and Billington, S. L., "Investigation of infill panels made from engineered cementitious composites for seismic strengthening and retrofit," Journal of Structural Engineering, Vol. 131, pp. 1712-1720 (2005).

8. Li, H., Zhang, M. H., and Ou, J. P., "Abrasion resistance of concrete containing nano-particles for pavement," Wear, Vol. 260, pp. 1262-1266 (2006).

9. Maalej, M., Hashida, T., and Li, V., "Effect of fiber volume fraction on the off-crack-plane fracture energy in strain hardening engineered cementitious composites," Journal of America Ceramal Society, Vol. 78, pp. 3369-3375 (1995)

10. Naaman, A. E., "Engineered steel fibers with optimal properties for reinforcement of cement composites," Journal of Advanced Concrete Technology, Vol. 1, pp. 241-252 (2003).

11. Song, P. S., Wu, J. C., Hwang, S., and Shen, B. C., "Assessment of statistical variations in impact resistance of high-strength concrete and high-strength steel fiber-reinforced concrete," Cement and Concrete Research, Vol. 35, pp. 393-399 (2005).

12. Swaddiwudhipong, S., Lu, H. R., and Wee, T. H., "Direct tension test and tensile strain capacity of concrete at early age", Cement and Concrete Research, Vol. 33, pp. 2077-2084 (2003).

13. Swaddiwudhipong, S. and Seow, P. E. C., "Modeling of steel fiber-reinforced concrete under multi-axial loads," Cement and Concrete Research, Vol. 36, pp. 1354-1361 (2006).

14. Yan, H., Sun, W., and Chen, H., "Effect of silica fume and steel fiber on the dynamic mechanical performance of high-strength concrete," Cement and Concrete Research, Vol. 29, pp. 423-426 (1999). 